\title{
CROSS CURRENTS...
}

a new quarterly revien

to explore the implicativis

of Christianity for our time

. . enters its second year of publication, continuing $1 \%$ reprint outstanding articles from out-of-the-way and foreign journals which indicate the relevance of religion to the intellectual life. Its first four numbers contained articles by ...

EMMANUEL MOUNIER - EMIL BRUNNER - MAX PICARD

MARTIN BUBER - HENRI DELUBAC - KARL BARTH

NICOLAS BERDYAEV - YVES CONGAR - GABRIEL MARCEL

MARYSE CHOISY - JEAN DANIEIOU • MARTIN TURIILUL

Numbers 2,3 , and 4 still available at $\$ 1$ each. Subscription $\$ 3$ a year.

CROSS CURRENTS, Bo: 18?, New York 27, N. Y.

\section{WORLD POLITICS}

A Quarterly Journal of International Re'ations

Vol. IV No. $1 \quad$ October 1951

Felix GilberT--The "New Diplomacy" of the Eighteenth Century Arnold Wolpers--The Pole of Power and the Pole of Indifference Mario Einaudi--The Crisis of Politics and Governinent in France Raymond L. Garthoff-The Concept of the Balance of Power in Sovict Policy-Making

PAvL E. Zinner-Problems of Communist Rule in Cizechoslovakia Revicw Article by DainIge. LeRner

Price: $\$ 5.00$ per year $\$ 1.50$ per copy

Center of International Studius - Princeton University Subscriptions: World Politiss, Rux 231, Princeton, N. J. 